\title{
Writing on the Edge: Gary Crew's Fiction
}

\author{
Alice Mills
}

$\sim>$ ary Crew is a prolific writer of literature for adolescents and younger children, distinguished by the darkness and mystery of his themes and by the exceptionally wide range of literary forms in which he writes. His teenage novels range from the contemporary social issues of The Inner Circle to Strange Objects' mixture of historical recreation, horror, social realism and the supernatural. His collaborative picture story books are still more diverse, from the quirky retelling of book 1 of Gulliver's Travels to the study of guilt and grief in Lucy's Bay; from the comic-book melodrama of Tagged to First Light's account of a fishing trip in which almost nothing seems to occur. Crew has ventured into satire with his send-up of teen romances in Inventing Anthony West, and into earnestly moral tales of talking animals. Only in his short stories is he predictable, favouring a novice policeman as his main character and mysteries that border on the macabre.

With a few exceptions like the talking animal books, each of which has a happy ending, almost all Crew's works of fiction are characterized by doubt. Whatever the format of his books, they rarely offer consolation; rather, they disquiet. It is often unclear whether characters are eccentric or extraordinarily cunning, or mad, or in touch with an alternative, equally valid reality. Crew's novels and short stories tend to finish with no resolution of the narrative, the fate of the main characters uncertain, the mysteries unsolved. During the second half of the twentieth century it has been common for teenage literature in the Western world to present grim themes and dubious or disastrous outcomes. Literature for younger children, however, is still dominated by the formulaic happy ending, as it has been throughout the twentieth century. Crew repeatedly denies the readers of his collaborative picture story books the reassurance of a straightforwardly happy ending, so much so that these books are frequently categorized in libraries as teenage fiction also. While he has won an impressive list of literary awards, his books have also been attacked on the grounds that they are too difficult, demanding and black for an audience of young children (Haigh 1991, p. 1).

For those readers who can relish uncertainty and bleak endings, Crew's works offer the sophisticated pleasures of explanations that confound the problems they fail to explain, of margins never quite established and boundaries never decisively crossed. Crew rarely produces fantasy fiction as the term is commonly understood; that is, fiction that goes decisively outside ordinary consensus reality. Yet the strange events, characters and objects that he writes about defy realist explanation. If fantasy is understood according to Todorov as the upserting, rather than transcending, of ordinary consensus reality (Stone 1992, p.31; McKenna and Neilsen 1992, p.21), Crew is one of the masters of fantasy in contemporary Australian literature.

The influence of Poe is evident in his stories of mystery and the macabre. As with Poe, madness and the supernatural stretch and subvert the everyday lives of his characters, who struggle to understand, even to survive, in a world where few can be trusted and little can be relied upon. Crew keeps open the possibilities of rational, realist explanation more completely than Poe: the supernatural may be at work, miracles and demonic possession may afflict his characters, but much can be accounted for as mere coincidence. To keep this span of interpretation open for the full length of a novel is Crew's achievement at his best.

Fiction that takes the form of riddle always tempts its readers to provide answers and force the indeterminate into definite form, to choose either a commonsense or a supernatural solution for each mystery, to decide if a puzzling character is trickster, madman or demon. At his least satisfactory, Crew himself succumbs to the pressure to explain and reassure his audience. At his strongest, he brings to the reader's notice the human need for a satisfactory story, the human need to make sense of the world. The power of his fiction derives not from meeting such needs but from playing upon them.

Crew's first novel for adolescents, The Inner Circle, is his most straightforward. Two Australian teenagers, the white Tony and the Aboriginal Joe, meet and transform one another's troubled lives. The book traces their psychological and social development. Alternate chapters are recounted by Joe and Tony, (a technique that foreshadows the multiple narrators of Strange Objects), but in this first novel both narrators are fully reliable, 
their accounts complementing and confirming each other. There is no reason for the reader to doubt or distrust until the closing pages. By this point the Aboriginal character has found an exceptionally promising career opening in the white world, and the white character has been welcomed into an Aboriginal family; their problems are thus given a sentimentally idealized solution, until in the last pages it is reported that Tony has disappeared.

$\mathrm{He}$ is the first of many young male characters in Crew's fiction who behave oddly, uncharacteristically, even disappear mysteriously at the end of a story. Tony's disappearance is not rendered plausible either by anything in his previous behaviour or by direct narration from Tony himself. Remote, distanced by two layers of reporting, the event momentarily opens the possibilities of an emotional breakdown or suicide. In later books such possibilities would be left open, but in this instance the mystery is no sooner posed than resolved. Tony is safe and well and has left in order to discover who he truly is. The Inner Circle is (to date) the only one of Crew's novels in which such total reassurance is possible, though at the cost of totally plausible characterization.

The temporary mystery of Tony's disappearance is an aberration in The Inner Circle. In contrast, The House of Tomorrow abounds in ambiguous clues, secrets and suspicions. Its strength lies in strategic silences. Doubts multiply around and within the main characters, haunted by a past and future that manifest in their dreams, the books they read, the voices they hear. The teachernarrator, $\mathrm{Mr} \mathrm{Mac}$, troubled by dreams of his dead wife and dead baby son, tries to compensate for his lack of family by becoming a father to all his students. During the novel he is forced to acknowledge his inadequacies as a father figure, and he eventually suffers a breakdown. When one of the students is found dead at the foot of a waterfall, it is never absolutely clear whether he has jumped in despair or was pushed. Another schoolboy dies in a fire - or did he too commit suicide?

At the centre of The House of Tomorrow's complicated story is Daniel Coley, a schoolboy obsessed with accounts of the dead returning to speak to the living and claim them. He has 'heard voices' (p.4) - or is this enigmatic comment at the end of his English essay just an exercise in creative writing on his part? From the moment that Daniel is brought to Mr Mac's attention, the teacher's responses are inadequate. When the boy behaves oddly in class, Mr Mac concludes that he is looking for attention and bullies him into conformity. When Daniel performs superbly in the school musical to please his teacher, $\mathrm{Mr}$ Mac barely acknowledges him for fear of being branded homosexual. When the boy keeps a personal joumal for Mr Mac as a form of therapy, the teacher first breaks confidentiality, then neglects to read and respond to later entries. When Daniel eventually dies in a fire, the reader is primed to suspect suicide, and to blame Mr Mac's neglect and cruelty.

Perhaps, though, Daniel's death is only an accident. His last communication to $\mathrm{MrMac}$ is affectionate and gratefu! rather than bitter (pp.179-180). If the statements in his letter are taken as the entire truth, Daniel's story can be read as a successful rite of passage through the problems of his adolescence, marred only by extreme bad luck. However, after the fire Mrs Coley writes a letter which provides at least one more layer of interpretation of Daniel's life and death. According to her letter, he is not her son but the adopted son of a part-Asian woman and her husband's brother, the man known to Daniel only as Uncle Keith, a soldier missing in action in Vietnam. The boy's obsession with the dead returning to claim the living can now be understood as a sign of his halfconscious awareness of his true parentage; or as a supernatural manifestation, the voices of his dead parents revealing his heritage, summoning him to join them.

If Daniel's death is suicide, none of his rival fathers is blameless. Mr Coley, his adoptive father, tries to mould the teenager into a living deach of obedience and repression. Daniel is loved, betrayed and emotionally damaged by Mr Mac, who longs to be the boy's father and yet shrinks from him in his need. If Daniel's voices are understood as ghostly phenomena, his blood-parents are summoning him to join them forever in death. Daniel's story can be read as a failed rite of passage, an ordeal set up by those terrible parents who together bring about his death.

'Terrible parents' is too strong a phrase, though. Mr Mac tries to keep a safe distance from any vulnerability of the heart. Mr Coley may rage and curse his son, but Daniel 
temporarily blossoms in spite of him. Daniel's voices, at first linked to stories of drowning, by the end of the novel accompany visions of earth's wonders in his grandparents' house

\section{... where his Euro/Asian identity is reconstructed - not from the limiting flesh and blood presence of his ancestors but from the dreaming ephemera of moonlight and lace and rafter and lintel and doorpost. \\ (Crew 1994a, p. 150)}

None of these parents, then, can simply be judged instrumental in Daniel's death.

Crew clains that the two main voices, $\mathrm{Mr}$ Mac's and Daniel's, are symmetrically balanced (McKenna and Neilsen 1992, p.20), but the teenager's voice is everywhere subordinated to Mr Mac's privileged voice as overall narrator. Daniel's passionate intensity is muffled by a multitude of adult reflections and judgments on his behaviour, reducing any disturbance for readers from the book's themes of shame, grief, love, suicidal despair, obsession and the visitation of the dead.

As Pearce points out $(1990$, p.54) the calamities of the narrative are partly balanced by images of rebirth. A distressed teacher finds peace in a Buddhist community, another marries happily, and $\mathrm{Mr}$ Mac ends the book enjoying his retirement at the beach. His narration concludes: '.. but that was years ago ... No. I cannot think of the past' (pp.184-5). Even here, though, Crew's phrasing disquiets. Mr Mac 'cannot think of the past', yet he has done nothing but think of the past throughout his narrative. Is he claiming here, none too convincingly, that his current happiness outweighs all the previous despair and death? Or is he trying to repress his story from memory, with its unsparing evidence of his weakness, cruelty and treachery? The book ends, as it has proceeded throughout, balanced between contradictory possibilities.

Crew's next novel, Strange Objects, also abounds in framing devices and troubling themes, but here each new unhelpful clue and contradictory comment intensifies the book's potential to disturb. The difference is partly due to the different outcomes of the main characters' lives. Daniel dies; Joe, Tony and Mr Mac live on in hope; the fates of Strange Objects' Wouter Loos, Jan Pelgrom and Steven Messenger are unknown, but most probably terrible. There is no comfort to be found in the book's two narrators, either. Loos and Steven Messenger are unreliable narrators, their motives for writing down their stories suspect, their truthfulness questionable, Steven's sanity in doubt. Crew invites the reader to pass judgment not only on the narrators but on almost every character in the novel, to speculate on almost every event: to judge, however, is to fall into a guilt trap (see Mills 1993a). In the two narratives and their accompanying commentaries, virtually every character and event is given several conflicting interpretations, each one morally charged. To choose any particular reading - that Steven is a psychopathic killer, for instance, or that Loos is a penitent murderer - is to have that reading challenged within the text or by a telling silence, either of which calls into question the reader's own morality. The Inner Circle reassures; The House of Tomorrow distances; Strange Objects offers little reassurance and no comfortable distance.

The twentieth-century plot of Strange Objects begins with the Australian teenager Steven Messenger's discovery of a 'cannibal pot' containing a journal and a mummified hand wearing a ring. By theft or accident Steven acquires the ring, and according to his account it gives him supernatural powers of time travel, levitation and flight. The ring attracts - or generates - a second Steven Messenger, though he may equally well be Steven's schizophrenic hallucination or a manifestation of the ring's seventeenth-century owner, the psychopathic killer Jan Pelgrom. Steven despises, fears and (probably) murders an Aboriginal elder who knows that he has the ring (see Mills 1993a, p. 199). Finally Steven disappears: murdered for the ring, perhaps, his dead body eaten by ants, or perhaps supematurally possessed, or perhaps terrorizing the highways as an insane mass murderer. Almost every event in Steven's story similarly disintegrates into unpleasant, incompatible possibilities. At the very end of the novel his mother reveals that his father died on the road months ago, a fact consistently denied by Steven himself. At this point much of his odd behaviour can be reinterpreted as symptoms of crazed grief; however, this does not explain why he should have 
assembled and posted the package of incriminating documents that make up Strange Objects. With the complex, enigmatic character of Steven Messenger, Crew enters fully into the territory between rational explanation, madness and Gothic horror presided over by Poe.

Together with the ring and severed hand, Steven discovers the journal of a seventeenth century sailor, Wouter Loos, cast away on the West Australian coast with the teenager Jan Pelgrom in punishment for their part in the Batavia massacre. Historical records exist for the wreck of the Batavia, the mass murder of its survivors and Loos' and Pelgrom's punishment. The joumal itself, though, is made up by Crew, mingling fact and fiction, archaeological, anthropological and geographical detail, supernatural phenomena and the story of what might have happened if Loos and Pelgrom had come safe to shore, had survived long enough to meet the local Aborigines and been accepted into their society. Setting aside the supernatural elements, Loos' journal is a postcolonial text, exposing the prejudices that, like the first (historically attested) European settlers of Australia, Loos and Pelgrom brought to bear on the Aborigines, and the overpowering advantages afforded them by European disease to which the Aborigines had no resistance. Even the ring's supposed supernatural powers, when it bestows a halo upon the murderer Pelgrom, can be read as a parody of Christ's powers to redeem, as preached by white missionaries intent on supplanting Aboriginal beliefs and ways of living.

Sirange Objects' allusions to earlier English literature are equally destructive of their sources. The ring, so precious to Pelgrom and Steven, alludes to Tolkien's ring without the consolation of Tolkien's moral universe: 'there is a dead end fantasy game or quest that occurs there' (McKenna and Neilsen 1992, p. 22). The fragments into which Loos' journal collapses, resemble the closing pages of Stephen Daedalus' diary in $A$ Portrait of the Artist as a Young Man; but where Joyce's Stephen ends with a triumphant welcome to life, having broken free from the old forms, Loos ends his story of grief and horror by faltering into silence. Crew's allusions to works such as Alice in Wonderland, The Pied Piper, King Solomon's Mines and The Coral lsland, 'sending up, or satirising, or nudging out of of the main stream the dated European fantasy context' (McKenna and Neilsen 1992, p.22) in no way celebrate his European heritage of story. The book's reworking of past literature into a set of dead ends, like its parody of Christian miracle and its refusal of narrative closure, is a post-modern exercise in meaninglessness.

Strange Objects undermines not only Westem literary and religious traditions but a range of other Western authorities also: the courts, the police, parents, scholars, historians, the printed word. Doubt is first cast on authority in the book's opening pages, purportedly written by a Dr Hope Michaels, Director of the Western Australian Institute of Maritime Archaeology, who ends with an appeal to the reader:

I trust that any reader who may have information on the whereabouts of Steven Messenger, or of the historic ring, will contact either myself or the police without hesitation.

(p.4)

All this is enough, perhaps, to leave a niggling uncertainty in at least the first-time reader's mind that she might really exist, that the story she introduces might be fact not fiction.

Doubts over the narrative's fictional status extend to the book's extracts from psychology, criminology and history texts and newspaper cuttings. The effect of such doubts is to attack the authority of written texts in general. History, when understood as a single, indubitable account of events, is further attacked whenever one of Strange Objects' multitude of voices contradicts another, whenever doubt is cast on the narrators' reliability (Crew 1991c).

As a postcolonial text, Strange Objects ridicules and attacks the traditional view of Australian history as seen through European eyes and judged by JudacoChristian values. Crew does not, however, disparage oral and pictorial history as practised by Australian Aborigines. He gives a place of honour to Charlie Sunrise, keeper of the Aboriginal sacred site, teller of the old stories. Steven refuses the chance to become initiated into Aboriginal secrets when he (probably) kills the old man (see Mills 1993a). Crew argues that at least one aspect of the book's ending offers hope of a better understanding between the 
races, when the Murchison District Aboriginal Council invites the local white policeman into their sacred site (McKenna and Neilsen 1992, p.18).

Part of Crew's indictment of Westem culture as patriarchal, repressive and murderous is the powerlessness of his female characters. Dr Michaels, observing and analyzing as a researcher, uses her scholarly authority to address Steven. Outside such Western systems of authority, women in Strange Objects are almost mute. Like Daniel's mother in The House of Tomorrow, Steven's mother finds an occasion to reveal the truth about the teenager's missing father only at the end of the novel when the men have had their say. In Loos' account, a female castaway from a separate shipwreck, Ela, speaks very little, functioning mainly as object for Loos' desire and the rapist Pelgrom's lust. In his treatment of male characters, Crew almost forces the reader into moral discomfort by the excess of contradictory evidence and conflicting judgements. In contrast, the female characters' lack of words could easily be taken for granted. In refraining from any explicit commentary or Ela's muteness and Mrs Messengers's long witheld testimony, the author runs the risk of being understood to endorse the silencing of women.

Ela's dead finger carries the ring across the centuries to Steven Messenger, on a hand severed not by her murderer Pelgrom but by the Aborigines. According to Charlie Sunrise, the seventeenth century Aborigines preserved the dead woman's hand as an amulet to 'keep away evil spirits' (p.15). Despite their intentions, Strange Objects' Aborigines transmit the ring's malignities from one white male murderer to another. It would be far easier to accept a version of these events in which Pelgrom himself mummifies Ela's hand and puts it in the cave for Steven to find, but the book's evidence all points (unusually clearly) to the Aborigines. Responsibility is thus put on Pelgrom's victims, Ela and the Aborigines, for providing a literal 'dead hand of the past' (Mills 1993b) to haunt the book's present. The distinction between victim and unconscious colluder becomes very shaky at this point.

Like Strange Objects, Crew's next novel, No Such Country: a Book of Antipodean Hours, tells of the killing of Australian Aborigines by white settlers. No Such
Country's atrocity is modelled on historically attested Aboriginal massacres and their temporary concealment in communal silence (Zahnleiter 1991, p. 17). Somewhere in tropical north-eastern Australia, close to a fictional volcano, in the fictional town of New Canaan, the white townspeople are collectively guilty of murdering the local tribe of Aborigines, all but one survivor, the pregnant Hannah. The crime is uncovered by a visiting anthropology student, Sam Shadows, and two local teenagers, Rachel and Sarah; their explorations of the community's secret make up much of the bonk's plot. Sam tums out to be Hannah's son, the last living member of the massacred tribe come to New Canaan to dig up his personal past along with an Aboriginal shell midden.

Most of the story of the massacre and its discovery is plausibly realist. The teenagers who dig up the bodies are as ordinary as New Canaan's repressive society and Sam's mysterious parentage allow, and they struggle with sexual attraction and jealousy in everyday, teenager fashion. The long expository section in which Sam reveals his past, however, shifts the book's register from realism to adventure romance. The volcano erupts at the novel's climax in good adventure romance style, freeing the town from its guilty past. This is Rider Haggard territory, full of convenience in the disposal of characters, coincidence and theatricalities on the part of the scenery.

Overlaying the story is a weight of Biblical allusion, amounting to a sustained attack on the Christian church as a colonial instrument of oppression, abuse and murder. The town is tyrannized over by a white-robed Father, punitive, hypocritical, sexually abusive, served by a local lout nicknamed Angel. Biblical references are similarly twisted throughout the book, much as in Strange Objects. In No Such Country, however, truth can almost always be known, good and evil can be simply distinguished and evil overthrown. Each chapter is named after an incident in Christ's birth and childhood, from 'signs and portents' through 'nativity' to 'massacre of the innocent' and 'in the temple'. Such references function allegorically rather than symbolically: the significance of 'in the temple', for instance, depends on the reader knowing the New Testament. Similarly, only a reader acquainted with the Bible will notice the ironic presentation of Sam as a 
secular Christ, a man of common sense rather than miraculous powers. Sam turns out to be the Father's unacknowledged son. At the novel's end it is the Father, not his son, who dies in atonement for the people's crime - another ironic twist dependent on the reader's knowledge of the Bible.

As allegory, No Such Country transposes Christianity's black and white, good and evil, so that the white Angel is the most loutish of its characters, the dark-skinned Aborigines the town's innocent victims. Crew does not pursue a totally rigid set of allegorical correspondences, however. Sam finds a second loving mother in the white director of the boys' home. He is educated, Western style, at university. By the novel's end, having found his racial identity, he chooses to go back to the white-suited scientists' world of Western science (McKenna and Neilsen 1992, p. 19). Not every aspect of the white world, then, is represented as corrupt.

Though it does not simply categorize all white characters as black of soul, No Such Country's allegory, like its adventure romance, is morally unambiguous. Characters are either innocent or guilty, loving or incapable of love. There is no doubt about what happens, either. The volcano definitely erupts, the Aborigines are indubitably massacred. Crew moves onto more doubtful ground (Poe territory between madness, lies and the supernatural), where the Father is concerned. This character cannot simply be allegorized as a figure for the corrupt church; still less, as Crew claims, as 'a paradigm of apparently ageless Empire' (McKenna and Neilsen 1992, p. 22), for he always exercises spiritual, not secular, authority.

Whether as con-man, megalomaniac or God, he is curiously peripheral to the story. He is said to dominate the townspeople's lives, but he does not (according to his Book of Hours) instigate the massacre. In the course of the narrative he does little but lurk threateningly, behaviour far less shocking and fascinating than Pelgrom's murderous antics or Steven Messenger's experiments with death. Ultimately the Father's disturbing ambiguities are swallowed up in No Such Country's mixture of adventure romance and allegory (and so the closed ending of those literary genres prevails over the open-endedness of the Father's post-modem presentation). Equally well, his death functions as a sign of divine retribution. The lava that literally swallowed him splits 'like the tongue of a serpent' (p.202), a simife which suggests both the devil come to claim his own and the Aboriginal Rainbow Serpent taking revenge. These possibilities are incompatible, but they are not as disturbing as the multiple readings of Steven's fate in Strange Objects, partly because this man's final fate is known, partly because he is a remote figure for most of the book, not its narrator, skulking in the margins that in this novel never threaten to take over the map.

In No Such Country, conflicts between good and evil, sinner and innocent, black and white, are mainly fought out between men, with women as their silent victims and colluders, helping to bury the murdered Aborigines and then enduring the Father's private visits. Half way through the book, Sam recognises another force, that of the planet: 'a strength that is [God's] equal, yet not so cold; a closer, warmer god of earth. A woman, even? A woman bedded-down deep in coals of fire?' ( $p .96$ ) From the sea's depths comes a monster that terrifies Angel for the rest of his life. From the earth's core comes the volcanic eruption that destroys New Canaan's bonepit, and with unconvincing suddenness heals the town's guilt. Crew has commented on the Freudian implications of the book's symbolic landscape, in particular the phallic cone of the volcano, that 'is symbolically the white father' (McKenna and Neilsen 1992, p.22), penetrating the upper air as the spire of the Father's church (a tottery erection) feebly imitates it below. In so far as the Father has been the instrument of engulfing (not piercing) retribution, it is symbolically feminine. The contest between patriarchal authority and female anger, between the Father and the teenager Rachel, between Rachel and Angel, cannot be won by the book's female characters in their own right, with their own bodily strength and will-power. Their anger takes symbolic form in the lava that flows and engulfs the Great White Father and his Angel. Sarah and Rachel are the most fully developed and sympathetic of Crew's female characters (so far), less fully contained within the patriarchal order than their mothers, less fully silenced than the mothers of Strange Objects and The House of Tomorrow. Though they defy the Father long before the volcano erupts, it is only by the symbolic 
killing of their patriarchal tormentor, enacted guiltlessly by the volcano rather than by their hands, that they can find freedom.

Three years later, in the novella Inventing Anthony West, Crew reconsiders the relationships between man and woman, again in terms of patriarchy and female rage, and again one literary genre overpowers another. Imventing Anthony West is the most accessible and playful of Crew's longer works of fiction, parodying the conventions of the teenage love story and horror film, but its denouement is much more sinister than the Father's death and the town's instant redemption in No Such Country.

Two teenage girls, stuck indoors for a weekend, amuse themselves by creating their ideal male teenager, 'Anthony West', from cut-out magazine images. Kate's ideal is intelligent, slim, perhaps a writer; Libby's is athletic, able to wield an axe. In turn the two girls daydream about meeting this image in the flesh; but daydream turns to nightmare when Anthony West proves a coward, betrayer and patriarchal bully. His intellectual version abandons Kate in a crypt and the athletic version leads Libby towards ritual death inside a volcano. The girls wake in horror and eventually decide to burn the doll, but they succeed only in charring its paper hands.

At the start of the book it seems as though Kate and Libby are half seriously practising witchcraft, but $\mathrm{Crew}$ retreats from his story's potential horrors, explaining it all away as bad dreams. Then, in the final short chapter, back at school, the girls meet their new neighbour - Anthony West - his hands burnt and bandaged. Parodied romantic fiction gives way to Gothic horror - or is this to be explained rationally as mere coincidence, or psychologically as an external projection of Kate and Libby's combined inner rage, the two teenagers functioning as each other's doubles? Has female sexual desire, female rage, been powerful enough to manifest and mutilate a lover supernaturally? Will the flesh and blood Anthony prove as unpleasant as the dream-figure, and are the girls' nightmare relationships about to recur in their waking world? What has been a slight, amusing, clever send-up of both Frankenstein and popular escapist fiction ends with a touch of grue, all the more powerful because of the previous explanations that it was nothing

\section{but a nightmare.}

Between No Such Country and Imventing Anthony West, Crew published $A$ ingel 's Gate, an orthodoxly realist novel with a reliable narrator and a fully resolved murder mystery. Angel's Gate is also a psychological study of the murdered man's two children, who flee into the Australian bush and become partly feral. Angel's Gate's teenagers attempt to be wild with limited success. The feral children are captured and imprisoned within the welfare system, while the doctor's teenage daughter attempts her own mild form of wildness, seeking out a part-time job and enjoying her boyfriend's company in defiance of her father (one of Crew's least effectual patriarchs). 'They get us all sooner or later' (p.2) is her comment when the first of the feral children is captured; but at the novel's end she continues to defy her father and subvert the future he has chosen for her (see Davison and Scutter 1993 for contrasting reviews of this text).

Of all Crew's longer works of fiction, The Blue Feather is the most consoling and the least ambiguous. (According to Sharyn Pearce (1997), its hope and promise are due to a process of collaboration with Michael O'Hara.) The troubled teenager Simon is an habitual runaway who is regularly recaptured by welfare officers, but 'they' do not get him in the end. Simon is sent for rehabilitation to a sanctuary for raptors, to work for its owner, Greg. Simon's habit of cocking his head to see (to compensate for the loss of one eye), his sense of being trapped and longing to run, are very similar to the behaviours of the damaged, caged birds of prey. When Greg and his former lover, the photojournalist Mala, invite him to a wildemess trip in search of a giant bird, he is simultaneously being invited to go in quest of his own healing and to undertake a rite of passage from adolescence to manhood. The expedition searches for visible, photographable evidence of a nest or food-remnants to determine whether the bird is mythical or exists in ordinary consensus reality; at the same time they are tested spiritually, required to trust, believe and surrender. They end by finding nests for themselves, Greg and Mala together, Simon with a new mother figure. The quest is almost fully successful for all three.

For a while, though, The Blue Feather hints at horror. One of Simon's eyes is missing, and he does not reveal 
until late in the book 'how, or why, or by whom it had been gouged, cut or poked from its socket' (p.14). Such phrasing (misleadingly) suggests a history of child abuse, and Crew and O'Hara may be alluding throughout the novel to another Simon, in Keri Hulme's The Bone People, victim of horrific physical abuse. Mutilation for The Blue Feather's Simon serves (more convincingly than for Hulme's Simon) as a means to psychological and spiritual - but not physical - healing for himself and the adults who care for him. In Crew's earlier novels, long-withheld truths like the secret of Simon's missing eye are told by mothers when their sons have disappeared or died, too late to make a difference to their lives. In this book, Simon himself manages to voice his own truth, to live through his initiation ordeals, to return after disappearing from camp and to find his own means of integration into everyday life.

Simon slowly learns to trust, to admit his needs, to ask for help, to acknowledge and use the gifts he is given - a backpack, a compass, water-bottle, balm, knife and feather. His ordeals run closely parallel to the hero-quest stages in Joseph Campbell's The Hero with a Thousand Faces (as cited in the epigraph). Like a thousand other heroes, he reluctantly accepts the call to adventure, then finds helpers along the way. He crosses a threshold from the normal everyday world into a symbolic landscape where his honesty and strength of character are tested, where he must suffer psychological death, passing through a laby rinth and entering an underworld. A flurry of allusions to resurrection, both Biblical and classical, surrounds the final revelation about the birds, indicating that they bring spiritual rebirth as well as psychological healing and initiation. How the characters see, and how they interpret what has been seen, marks their development in healing and grace. The scientifically minded Mala, like Doubting Thomas, needs to see with her physical faculties in order to be sure; Greg (echoing the New Testament) can believe without seeing, and it is one-eyed Simon, in the tradition of blind seers like Teiresias, who has the fullest vision of the birds.

The Blue Feather's use of symbolism runs the risk of becoming sentimental. The quest is quickly accomplished, the helpers very heipful, the symbolism spelled out, the happy ending predictable. There is, however, enough toughness in the text to keep it from sentimental excess. For all their symbolic weighting as eagle, albatross, phoenix, constellation of stars and Holy Spirit, the giant birds have attacked and killed men. The quest follows a path from one death to another. At the happy ending, Simon still has a glass eye and his history of problems with welfare agencies is unresolved. The giant birds - if they exist in the everyday world - are in danger of being shot, or poisoned with radiation sickness, or caged and put in a zoo. The book's ending is not altogether consoling, nor does it offer complete narrative closure.

There is a curious mixture of freedom and spiritual determinism in The Blue Feather. Greg is scrupulous in allowing Simon freedom to choose, but Simon cannot understand his own willingness to stay at the sanctuary, to keep Greg and Mala company on their trek, to pursue his quest for the giant bird, to accept guidance. Towards the end of the book, spiritual guidance blurs into spiritual compulsion, potentiaily as lethal for Simon as the forces that (probably) possess Steven Messenger, whisper to Daniel Coley, erupt in No Such Country and animate the cut-out doll in Inventing Anthony West. Whatever directs his quest - and the epigraph from Campbel! invites an archetypal reading - proves benevolent, but is far from safe.

Simon's quest has mythic resonances. In Crew's next book, Mama's Babies, the heroine Sarah is more of a fairy tale character, a Cinderella whose substitute mother forces her into household slavery. The book's first page reveals its straightforward plot, the murderous career of an $1890 \mathrm{~s}$ baby farmer, sentenced to death as the result of a girl's testimony. Sarah's story is told almost entirely in realist terms, until in the midst of her ordeals she is visited briefly by a phantom in the form of her mother by birth. In so far as Sarah is a Cinderella figure it might be expected that her mother's spirit would aid her in sentimental Victorian style, but the phantom neither aids nor threatens her. The episode seems an odd venture into the supernatural when every other aspect of the story is explicable within the boundaries of ordinary consensus reality. This loving mother reappears as flesh and blood at the baby farmer's trial, and then claims Sarah for a 
happy-ever-after life of aristocratic pleasure, with no discussion of her ghostly manifestation. In this book, then, Crew does not so much cast doubt on the boundaries of consensus reality as momentarily defy them, with little effect on the plot or characters.

Most of Crew's short stories and novellas deal with the darker possibilities of spiritual and paranormal visitation. Their plots mainly concern mysterious crimes and strange deaths. As in Angel's Gate a novice policeman is often the chief suspect, but only in three stories, 'The Last Cabinet', 'Self Portrait' and 'A Step Behind', is the solution within the boundaries of ordinary consensus reality. ('The Last Cabinet' may also be read as an unpleasant reworking of Snow White. See Mills in Bradford, 1996) In most of the other stories, supernatural forces pull characters towards their death: by way of their fascinating oddity in the relatively cheerful 'Face to Stony Face'; through an almost Dickensian, sentimental promise of union with a loving heavenly family in 'Madonna of the Streets'; by way of hoax telephone calls in 'The Fourth Call from Jindra'; by ghostly re-enactment of an old crime in 'The Staircase'; by ghostly invitation in The Well; by an invitation to stay overnight in The Bent-Back Bridge; by The Barn's lure of the prehistoric. These stories are wellcrafted variations on Gothic horror and the macabre, each avoiding formula with its clever final twist.

The Well, The Bent-Back Bridge and The Barn are the first three books in the After Dark series of 'stories to make your hair curl'. Edited by Crew, After Dark is marketed as a competitor to the American Goosebumps series, for children who have gained some independent reading skills but need the encouragement of short books with short chapters. Each book includes full-page black and white illustrations. While for many of the later After Dark volumes the illustrations are integral to the work, modifying the verbal text, providing crucial clues, for Crew's three novellas they are an enjoyable extra. The Bent-Back Bridge was first published as an unillustrated short story and here, in particular, the words stand well alone.

The Bent-Back Bridge reworks Norse legends about trolls under bridges, and specifically 'The Three Billy Goats Gruff. Janet, the plump schoolgirl from whose point of view the story is told, is a solitary victim, lured to the bridge at night by the promise of friendship. No other human being, no guile on Janet's part, will protect her from the shape shifter who has taken the form of Lola, a new girl at school, to offer friendship and an invitation to stay overnight. Janet's wretched school life is sketched out, her size, unattractiveness, habit of cheating, neediness, her complete vulnerability to any offer of friendship. The shape-shifting monster under the bridge mimics her victim physically, as another schoolgirl, and morally, as a thief. 'Friend,' Janet cries out as the monster tears at her life (p.45) - or is this word spoken by the monster in final mimicry of Janet's hunger for love?

Hunger for love, hunger for the kill, are the motivating forces of The Well also. As in several of Crew's novels, an unpleasant family truth is finally revealed by a mother. Adam and Seth's grandmother is forced to admit that her son, their father, had a twin brother who died at the age Adam and Seth are now. Tom committed suicide when his father died, believing the other twin to be their mother's favourite. Seth, Adam's twin, is drawn to the well in which Tom died, in which his livid ghost manifests to lure the boy to his death. It seems as though the grandmother's love breaks the malign pattern, saving Seth, until the story's final description of the boy's 'cold, wet lips' and 'stony tongue' (p.48). Seth may be alive, but only as the living dead.

Carter, in The Barn, rejoices in the prehistoric life he discovers in the swamp. This eleven year old citysophisticate furiously resents his parents' move to the country until he comes to identify with two predatory dinosaurs in the barn, a pair as much out of place in the twentieth century as he is at the local school. To Carter, the prehistoric creatures mean a secret power that can sustain him through all the embarrassments and humiliations of his new life: the same promise, in fact, as Lola seemed to offer. The Barn ends with Carter's jubilation, leaving to the reader's imagination any horrors to come.

Carter experiences the safe thrills of disobeying his parents and viewing prehistoric creatures. Crew's fiction is rarely so safe, or so reassuring. The power of his work is not usually emotional, as in The Bent-Back Bridge, for 
although his characters often suffer, attention is drawn to the puzzles and ambiguities of their lives rather than their emotional crises. Conventional horror fiction sets up puzzles and ambiguities, withholding the revelation of the murderer's identity, of the monster's physical form, to intensify suspense, but always with the guarantee of a revelation to come. The distinctive post-modem quality of Crew's writing at its best is its excess of answers that amounts to no answer at all, its refusal of the grand revelation, its celebration of doubt.

Crew's fascination with inadequate fathers takes the forms of rivalry among his father figures, uncertain parentage, attacks on patriarchs and the death of their many-fathered sons. In a fictional universe where there are too many fathers, mothers are generally passive, inadequate, silent guardians of the family secret. Mama's Babies explores a fairytale fictional universe where there are too many mothers, the missing good mother and the sinister substitute mother who withholds the secret of the daughter's true parentage. In such worlds as these, with too many parents, the adolescent's rite of passage to womanhood or manhood is in danger of collapse, through rape or murder, and ordinary consensus reality is in danger of collapsing into psychotic or supernatural nightmare. To move from this confused and doubtful arena into the world of fantasy quest, as in The Blue Feather, is a relief that Crew rarely affords his readers. instead, he insists upon the exasperating, exhilarating uncertainties of writing on the edge.

\section{REFERENCES}

Crew, Gary (1994a) 'The architecture of mennory', in A. Nieuwenhuizen (ed) The Written World: Youth and Literature. Port Melbourne, Thorpe.

Crew, Gary (1992) Angel's Gote. Melboume, Heinemann.

Crew, Gary (1995a) The Barn, illustrated T. Jellett. Port Melbourne, Lothian.

Crew, Gary (1995b) The Bent-Back Bridge, illustrated G. Rogers. Port Melbourne Lothian.

Crew, Gary (1994a) 'Face to Stony Face', in L. Sussex (ed) The Lottery. Norwood, S.A, Omnibus..
Crew, Gary (1995c) 'The Fourth Call from Jindra', in M. McLeod (ed) The Phone Book. Sydney, Random House.

Crew, Gary (1988) The House of Tomorrow. Melbourne, Heinemann.

Crew, Gary (1986) The Inner Circle. Melbourne, Heinemann.

Crew, Gary (1994b) Inventing Anthony West. St Lucia, UQP.

Crew, Gary (1991a) 'The Last Cabinet', in L. Hathorn (ed) The Blue Dress, Melboume, Heinemann.

Crew, Gary (1994c) 'Madonna of the Streets', in A. Nieuwenhuizen (ed) Family: A Collection of Short Stories. Melboume, Heinemann.

Crew, Gary (1998) Mama's Babies. Port Melboume, Lothian.

Crew, Gary (1991b) No Such Country. Melbourne, Heinemann.

Crew, Gary (1997) 'Self Portrait', in Crew's 13: Classic Tales of the Macabre and Fantastic, illustrated Shaun Tan. Sydney, ABC Books.

Crew, Gary (1995d) 'A Step Behind', in A. Nieuwenhuizen and T. Duder (eds) Crossing. Melboume, Heinemann.

Crew, Gary (1995e) 'The Staircase', in Dark House. Melboume, Heinemann.

Crew, Gary (1990). Strange Objects. Melbourne, Heineman.

Crew, Gary (199lc) 'Strange Objects', Reading Time 35, 3, 11-12.

Crew, Gary (1996) The Well, illustrated N. Oliver. Port Melboume, Lothian.

Crew, Gary, with Michael O'Hara (1997) The Blue Feather. Melbourne, Heinemann.

Davison, Liam and Scutter, Heather (1993) 'Two viewpoints on Gary Crew's Angel 's Gate ', Viewpoint: On Books for Young Adults 1, 4, 16-18.

Haigh, Gideon (1991) 'Kid literati', The Age (Tempo section), 20 November, pp. 14 .

McKenna, Bemard, and Neilsen, Philip (1992) 'Post- 
colonialism, justice and good stories: An interview with Gary Crew', Imago 6, 2, pp.14-30.

Mills, Alice (1993a) 'Scapegoats and shadows: A Jungian account of the theme of collective guilt in Strange Objects', in M. Stone (ed) Australian Children's Literature: Finding a Voice, University of Wollongong, New Literatures Research Centre, pp. 197-202.

Mills, Alice (1993b) 'Written in blood: So Much to Tell You and Strange Objects', Papers: Explorations into Children's Literature 4, 1, 38-41.

Mills, Alice (1996) 'Aphrodite in a blue dress', in C. Bradford (ed) Writing the Australian Child, Nedlands, W.A., University of Western Australia Press.

Pearce, Sharyn (1990) 'Identity in Australia: Gary Crew's adolescent novels', Papers: Explorations into Children's Literature 1, 2, 51-58.

Pearce, Sharyn (1997) 'Writers at work: Collaborating on The Blue Feather', Reading Time 41, 4, 16.

Stone, Michae! (1992) 'The ambiguity of hesitation in Gary Crew's Strange Objects', Papers: Explorations into Children's Literature 3, 1, 18-27.

Zahnleiter, Joan' (1991) 'Know the author: Gary Crew', Magpies 4, 4, 17-19.

\section{ACKNOWLEDGEMENT}

The author of the article wishes to acknowledge the assistance of Gary Crew with the bibliographical details, and Marcia Pope for helping to improve the structure of the argument.

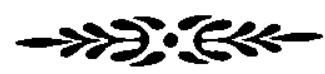

\section{BIOGRAPHICAL NOTE}

Alice Mills is a senior lecturer in literature and children's literature at the University of Ballarat. Her research interests include fantasy, myth and picture story books. She has published widely in the field of children's literature, and has edited the Random House Children's Treasury as well as Favourite Bedtime Stories (1998).

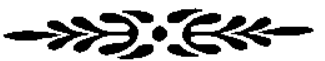

